\title{
LEGAL STANDARDS OF MILK DELIVERED FOR PROCESSING IN BRAZIL
}

\author{
ADEQUAÇÃO AOS PADRÕES LEGAIS DE LEITE ENTREGUE PARA \\ BENEFICIAMENTO NO BRASIL
}

\section{Samera R BRUZAROSKI ${ }^{1}$; Italo B TRENTO ${ }^{1}$; Sarah REZENDE ${ }^{1}$; Flavia AB PEREIRA ${ }^{2}$; Bruno G BOTARO ${ }^{3}$; Joice SIFUENTES DOS SANTOS ${ }^{3}$; Agostinho LUDOVICOㅜ; EIsa HW SANTANA ${ }^{3}$}

1. Alunos do Curso de Medicina Veterinária, Universidade Norte do Paraná - UNOPAR, Londrina, PR, Brasil; 2. Mestre em Ciência e Tecnologia de Leite e Derivados - UNOPAR, Londrina, PR, Brasil; 3. Docentes do Mestrado em Ciência e Tecnologia de Leite e Derivados - UNOPAR, Londrina, PR, Brasil.

\begin{abstract}
Thresholds for Somatic Cell Counts (SCC) and Total Bacterial Counts (TBC) in refrigerated raw milk have been stricter in Brazil since July 2014. We evaluated whether the composition of 11,051 milk samples delivered to processing plants in Paraná state, Brazil, by cooperative dairy farms, complies with government requirements and established changes. Milk quality was evaluated from June to August 2014, from dairy farms in three states. Data were obtained by infrared spectroscopy and flow cytometry. SCC was highest in June $(\mathrm{p}<0.05)$, when the highest number of samples and mean values was observed that did not comply with legal standards. No samples obtained in July complied with the requirements. The city in Mato Grosso do Sul state was the only one that met the legal requirements throughout the period studied. TBC did not vary $(\mathrm{p}>0.05)$ in the trimester, and none of the cities presented values below the maximum TBC allowed. Protein, fat and non-fat solids obtained complied with legal requirements. Total solids and lactose varied among the months $(\mathrm{p}<0.05)$, with highest values for total solids in June and for lactose in August. Milk samples did not comply with minimal requirements for SCC and TBC, and were not adjusted to more rigid quality standards.
\end{abstract}

KEYWORDS: TBC. SCC. Composition. Regulation. Quality.

\section{INTRODUCTION}

From January to March, 2014, 6.1 billion liters of milk were processed by the Brazilian dairy industries, an $8.9 \%$ increase compared with the same period in 2013. A total of $41.4 \%$ of Brazilian milk gross production was delivered to the Southeastern region (27.6\% delivered to Minas Gerais State industries) and $33.8 \%$ of Brazilian dairy production was directed to the Southern region industries (13.7\% to Rio Grande do Sul and $11.7 \%$ to Paraná states) (IBGE, 2014). As Brazilian milk production increased, national regulation on the subject had to be implemented (Brasil, 2011) aiming for the supply of high value end products to meet domestic and international market demands.

The Ministry of Agriculture, Livestock and Supply (MAPA) therefore established the Brazilian milk ordinance 62 (Brasil, 2011) to regulate milk production at farm level, through the identity and quality of refrigerated raw milk. Cooling raw milk on dairy farms, bulk milk transportation and quality parameters were then standardized. In Southern and Southeastern regions the Brazilian regulation has limited both Somatic Cell Counts (SCC) and Total Bacterial Counts (TBC) in refrigerated raw milk to 600,000 cells $\mathrm{mL}^{-1}$ and 600,000 CFU $\mathrm{mL}^{-1}$, respectively, until June $30^{\text {th }} 2014$. Then, from July $1^{\text {st }} 2014$ standards would become stricter, and raw milk quality parameters had to comply with new upper limits of TBC $\left(300,000 \mathrm{CFU} \mathrm{mL}^{-1}\right)$ and SCC $\left(500,000\right.$ cells $\left.\mathrm{mL}^{-1}\right)$. Compositional requirements, however, remained at their lower limits previously established for protein $(2.9 \%)$, fat (3\%) and non-fat solids (NFS) $(8.4 \%)$.

Milk cooling after milking, isothermal bulk hauling to the dairy and its storage under refrigeration are fundamental to reduce mesophilic bacteria responsible for raw milk titrable acidity increase (ARCURI et al., 2006). High mesophilic counts observed by the increase in TBC, for instance, clearly indicate poor milking practices whilst SCC at bulk tank levels are affected by failures in overall dairy herd health management, as determined by intramammary infections (BASTAN et al., 2008; FONSECA; SANTOS, 2000).

Thus, this study aimed to investigate whether overall raw milk quality complied with the recently revised upper limits as established by the Brazilian milk ordinance, from a dairy cooperative prospective.

\section{MATERIAL AND METHODS}

Data used in this study were collected from a dairy central cooperative in Southern Brazil, from 
June to August 2014, accumulating 11,051 observations. Bulk tank samples were collected monthly and milk composition analyses were performed using Bentley 2000 (Bentley Instruments, Chaska, $\mathrm{MN}$ ) to determine fat, protein, lactose, total solids (TS) and non-fat solids (NFS) percentages, Somacount 300 (Bentley Instruments, Chaska, MN) and BactoScan (Foss Electric, Hillerød, Denmark) for SCC and TBC, respectively. The samples were collected from dairy farmers whose milk production was delivered every other day to that cooperative. Dairy farmers were located in counties in three Brazilian states: Rio Bonito do Iguaçu, Londrina, Cascavel and Pato Branco counties (Paraná State PR); Batayporã county (Mato Grosso do Sul State MS) and São Martinho county (Rio Grande do Sul State - RS).

The effect of establishing the revised upper TBC and SCC limits of the Brazilian milk ordinance on data obtained immediately before and immediately after its implementation (July, 1 2014) (Brasil, 2011) was measured by the Kruskal-Wallis $(\mathrm{p}<0.05)$ and Mann-Whitney $(\mathrm{p}<0.05)$ tests.

\section{RESULTS}

Table 1 shows values of SCC, TBC, fat, protein, lactose, TS and NFS in milk delivered to a dairy industry located at Paraná, Brazil, from Paraná, Mato Grosso do Sul and Rio Grande do Sul States, from June to August 2014.

The mean SCC (Table 1) obtained during June was higher than that from July and August $(p<0.05)$. An increased number of samples which SCC $(53.86 \%)$ that would not comply with the new, revised regulation was observed in June 2014 $\left(600,000\right.$ cells $\left.\mathrm{mL}^{-1}\right)$ (Brasil, 2011). Nonetheless, when the revised SCC limit was reduced to 500,000 cells $\mathrm{mL}^{-1}$, a decrease in samples not complying with the standardized regulation was observed in July and August, $2014 \quad(49.5$ and 47.6\%, respectively).

Table 1. Mean, minimum, maximum and non-compliant * values of somatic cell counts (SCC), total bacterial counts (TBC), fat, protein, lactose, total solids (TS) and non-fat solids (NFS) in milk delivered to a dairy industry located at Paraná, Brazil, from Paraná, Mato Grosso do Sul and Rio Grande do Sul States, from June to August 2014.

\begin{tabular}{|c|c|c|c|c|c|c|}
\hline \multirow{2}{*}{$\begin{array}{c}\text { Month } \\
\text { Analysis }\end{array}$} & \multicolumn{2}{|c|}{ June } & \multicolumn{2}{|c|}{ July } & \multicolumn{2}{|c|}{ August } \\
\hline & $\begin{array}{c}\text { Mean } \\
\text { (Min-Max) }\end{array}$ & $\mathrm{NC}^{\dagger} \%$ & $\begin{array}{c}\text { Mean } \\
\text { (Min-Max) }\end{array}$ & $\mathrm{NC}^{\dagger} \%$ & $\begin{array}{c}\text { Mean } \\
\text { (Min-Max) }\end{array}$ & $\mathrm{NC}^{\dagger} \%$ \\
\hline $\begin{array}{c}\mathrm{SCC} \\
\left(\times 10^{3} \text { cells } \mathrm{mL}^{-1}\right)\end{array}$ & $\begin{array}{c}678.2^{\mathrm{a}} \\
8.0-950.0\end{array}$ & 53.8 & $\begin{array}{c}642.2^{\mathrm{b}} \\
10.0-8132.0\end{array}$ & 49.5 & $\begin{array}{c}646.0^{\mathrm{b}} \\
10.0-950.0\end{array}$ & 47.6 \\
\hline $\begin{array}{c}\text { TBC } \\
\left(\times 10^{3} \mathrm{CFU} \mathrm{mL}^{-1}\right)\end{array}$ & $\begin{array}{c}1001.5^{\mathrm{a}} \\
1.0-999.0\end{array}$ & 55.0 & $\begin{array}{c}993.3^{\mathrm{a}} \\
1.00-999.0\end{array}$ & 54.7 & $\begin{array}{c}1045.4^{\mathrm{a}} \\
1.0-999.0\end{array}$ & 54.8 \\
\hline Fat (\%) & $\begin{array}{c}3.9^{\mathrm{a}} \\
2.5-6.0\end{array}$ & 2.5 & $\begin{array}{c}3.9^{\mathrm{b}} \\
2.5-6.0\end{array}$ & 2.8 & $\begin{array}{c}3.7^{\mathrm{c}} \\
2.5-6.0\end{array}$ & 4.6 \\
\hline Protein $(\%)$ & $\begin{array}{c}3.3^{\mathrm{a}} \\
2.4-4.6\end{array}$ & 2.2 & $\begin{array}{c}3.3^{\mathrm{b}} \\
1.9-4.4\end{array}$ & 3.7 & $\begin{array}{c}3.2^{\mathrm{c}} \\
2.3-4.3\end{array}$ & 4.7 \\
\hline Lactose (\%) & $\begin{array}{c}4.4^{\mathrm{b}} \\
2.7-4.9\end{array}$ & $\mathrm{~N}$ & $\begin{array}{c}4.4^{\mathrm{b}} \\
2.4-5.5\end{array}$ & $\mathrm{~N}$ & $\begin{array}{c}4.4^{\mathrm{a}} \\
2.3-5.1\end{array}$ & $\mathrm{~N}$ \\
\hline TS (\%) & $\begin{array}{c}12.6^{\mathrm{a}} \\
8.4-15.3\end{array}$ & $\mathrm{~N}$ & $\begin{array}{c}12.5^{\mathrm{b}} \\
7.5-14.9\end{array}$ & $\mathrm{~N}$ & $\begin{array}{c}12.4^{\mathrm{c}} \\
8.1-15.3\end{array}$ & $\mathrm{~N}$ \\
\hline NFS (\%) & $\begin{array}{c}8.7^{\mathrm{a}} \\
5.8-10.0\end{array}$ & 14.8 & $\begin{array}{c}8.6^{\mathrm{b}} \\
4.9-10.2\end{array}$ & 20.6 & $\begin{array}{c}8.6^{\mathrm{b}} \\
5.4-9.8\end{array}$ & 19.6 \\
\hline $\begin{array}{c}\text { Number of } \\
\text { samples }\end{array}$ & 3,414 & & 3,621 & & 4,016 & \\
\hline
\end{tabular}


Table 2 shows SCC, TBC, fat, protein, lactose, TS and NFS in milk delivered to a dairy industry located at Paraná, Brazil, from Rio Bonito, Londrina, Cascavel, Pato Branco (Paraná State), Batayporã (Mato Grosso do Sul State) and São Martinho (Rio Grande do Sul State) counties, in June and August 2014.

As data were analyzed by municipality (Table 2), the lowest SCC values were observed in raw milk from Londrina (PR) and Batayporã (MS) $(p<0.05)$. The smallest number of samples not complying with the revised regulation (Brasil, 2011) was observed in milk delivered in June from Batayporã (MS) county farmers and in August from Londrina dairy farms (PR) (Table 2). Batayporã (MS) was the sole municipality where mean SCC values were in compliance with the revised milk ordinance before (June, 2014) and after (August, 2014) its establishment. In August, milk from São Martinho (RS) presented the highest SCC mean $(p<0.05)(61.6 \%$ of non-compliant samples).

TBC mean values did not change $(p>0.05)$ within the evaluated period and $52.4 \%$ of the samples did not comply with the TBC upper limit regulation before July $1^{\text {st }}, 2014\left(600,000\right.$ cells $\left.\mathrm{mL}^{-1}\right)$. Milk samples from Londrina (PR) and Batayporã (MS) had the lowest $(\mathrm{p}<0.05)$ TBC immediately before (June 2014) and immediately after (August 2014) the milk ordinance implementation (Table 2). Not only was Londrina the municipality in the study with the smallest number of milk samples not complying with the Federal regulation in June and August, 2014 (Table 2), but it also had the lowest TBC $(\mathrm{p}<0.05)$.

Milk TBC means from Londrina, Cascavel and São Martinho did not differ $(\mathrm{p}>0.05)$ before (June, 2014) and after (August, 2014). However,
São Martinho had the highest number of noncomplying samples $(60.6 \%)$. None of the investigated counties presented TBC in accordance with the regulated standards (Brasil, 2011).

Milk composition parameters for refrigerated raw milk on July, $1^{\text {st }} 2014$ remained as they were (Brasil, 2011). Mean protein, fat and nonfat solids values during the three evaluated months (June, July and August, 2014) and in the municipalities that delivered the milk (Table 2) are in accordance with the legal standards of the Brazilian milk quality regulation (Brasil, 2011). Fat and protein were different $(\mathrm{p}<0.05)$ during the months evaluated, with an increased number of noncompliant samples (Table 1) and a decrease in both values (Table 2) in August $(\mathrm{p}<0.05)$ compared to June, 2014. Non-fat solids were higher in June $(\mathrm{p}<0.05)$ with a lower number of non-compliant samples (Table 1). Regarding the municipalities, the highest non-fat solid values were observed in samples from Rio Bonito, Pato Branco and Batayporã, with significant differences $(\mathrm{p}<0.05)$ between June and August (Table 2).

Mean lactose values were higher in August than in June and July in the same year $(\mathrm{p}<0.05)$ (Table 1). With regard to the municipalities, São Martinho presented the lowest mean lactose values, whilst Rio Bonito and Cascavel lactose mean values did not differ between June and August $(\mathrm{p}<0.05)$ (Table 2).

Mean total solids levels varied among the three months $(\mathrm{p}<0.05)$, with higher levels in June, due to higher fat and protein levels (Table 1). A significant difference $(\mathrm{p}<0.05)$ was observed in June and August for each municipality (Table 2). 


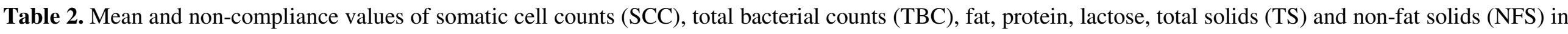
milk delivered to a dairy industry located at Paraná, Brazil, from Rio Bonito, Londrina, Cascavel, Pato Branco (Paraná State), Batayporã (Mato Grosso do Sul State) and São Martinho (Rio Grande do Sul State) counties, in June and August 2014.

\begin{tabular}{|c|c|c|c|c|c|c|c|c|c|c|c|c|}
\hline \multirow{2}{*}{$\begin{array}{c}\text { Municipality } \\
\text { Month/ } \\
\text { Analysis }\end{array}$} & \multicolumn{2}{|c|}{ Rio Bonito } & \multicolumn{2}{|c|}{ Londrina } & \multicolumn{2}{|c|}{ Cascavel } & \multicolumn{2}{|c|}{ Pato Branco } & \multicolumn{2}{|c|}{ Batayporã } & \multicolumn{2}{|c|}{ São Martinho } \\
\hline & Jun & Aug & Jun & Aug & Jun & Aug & Jun & Aug & Jun & Aug & Jun & Aug \\
\hline $\begin{array}{c}\mathrm{SCC} \\
\left(\times 10^{3} \text { cell } \mathrm{ml}^{-1}\right)\end{array}$ & $\begin{array}{c}765.2^{\mathrm{aA}} \\
(59.6)\end{array}$ & $\begin{array}{c}631.5^{\mathrm{aB}} \\
(51.3)\end{array}$ & $\begin{array}{c}600.6^{\mathrm{cA}} \\
(40.3)\end{array}$ & $\begin{array}{c}453.5^{\mathrm{bB}} \\
(25.5)\end{array}$ & $\begin{array}{c}568.0^{\mathrm{aA}} \\
(40.3)\end{array}$ & $\begin{array}{c}682.8^{\mathrm{aB}} \\
(50.6)\end{array}$ & $\begin{array}{c}755.8^{\mathrm{aA}} \\
(66.7)\end{array}$ & $\begin{array}{c}625.6^{\mathrm{aB}} \\
(49.1)\end{array}$ & $\begin{array}{c}555.9^{\mathrm{bA}} \\
(28)\end{array}$ & $\begin{array}{c}428.7^{\mathrm{bA}} \\
(30)\end{array}$ & $\begin{array}{c}837.8^{\mathrm{aA}} \\
(65)\end{array}$ & $\begin{array}{c}767.4^{\mathrm{cB}} \\
(61.6)\end{array}$ \\
\hline $\begin{array}{c}\text { TBC } \\
\left(\times 10^{3} \mathrm{CFU} \mathrm{ml}^{-1}\right)\end{array}$ & $\begin{array}{c}1192.2^{\mathrm{aA}} \\
(67.7)\end{array}$ & $\begin{array}{c}1173.2^{\mathrm{aB}} \\
(51.3)\end{array}$ & $\begin{array}{c}862.2^{\mathrm{bA}} \\
(38.5)\end{array}$ & $\begin{array}{c}888.8^{\mathrm{bA}} \\
(32.2)\end{array}$ & $\begin{array}{c}925.9^{\mathrm{aA}} \\
(42.9)\end{array}$ & $\begin{array}{l}1330^{\mathrm{aA}} \\
(61.7)\end{array}$ & $\begin{array}{l}1141^{\mathrm{aA}} \\
(58.0)\end{array}$ & $\begin{array}{l}1087^{\mathrm{aB}} \\
(52.7)\end{array}$ & $\begin{array}{c}887.7^{\mathrm{bA}} \\
(48)\end{array}$ & $\begin{array}{c}1320.7^{\mathrm{bB}} \\
(53.3)\end{array}$ & $\begin{array}{c}950.6^{\mathrm{aA}} \\
(59.4)\end{array}$ & $\begin{array}{c}1179.5^{\mathrm{cA}} \\
(60.6)\end{array}$ \\
\hline $\begin{array}{l}\text { Fat } \\
(\%)\end{array}$ & $\begin{array}{l}4.0^{\mathrm{aA}} \\
(2.2)\end{array}$ & $\begin{array}{l}3.8^{\mathrm{bdB}} \\
(40.2)\end{array}$ & $\begin{array}{l}3.9^{\mathrm{bA}} \\
(3.2)\end{array}$ & $\begin{array}{l}3.6^{\mathrm{cB}} \\
(4.1)\end{array}$ & $\begin{array}{l}3.8^{\mathrm{bdA}} \\
(2.0)\end{array}$ & $\begin{array}{l}3.7^{\mathrm{cB}} \\
(6.2)\end{array}$ & $\begin{array}{l}4.1^{\mathrm{cA}} \\
(1.8)\end{array}$ & $\begin{array}{l}3.9^{\mathrm{bB}} \\
(2.0)\end{array}$ & $\begin{array}{c}3.9^{\mathrm{adA}} \\
(4.7)\end{array}$ & $\begin{array}{c}3.5^{\mathrm{aB}} \\
(13.0)\end{array}$ & $\begin{array}{l}4.0^{\mathrm{aA}} \\
(0.9)\end{array}$ & $\begin{array}{l}3.8^{\mathrm{dB}} \\
(1.5)\end{array}$ \\
\hline $\begin{array}{l}\text { Protein } \\
(\%)\end{array}$ & $\begin{array}{l}3.3^{\mathrm{acA}} \\
(1.1)\end{array}$ & $\begin{array}{l}3.2^{\mathrm{aB}} \\
(5.7)\end{array}$ & $\begin{array}{l}3.3^{\mathrm{aA}} \\
(2.0)\end{array}$ & $\begin{array}{l}3.2^{\mathrm{acB}} \\
(2.5)\end{array}$ & $\begin{array}{l}3.3^{\mathrm{bA}} \\
(2.2)\end{array}$ & $\begin{array}{l}3.2^{\mathrm{cB}} \\
(6.0)\end{array}$ & $\begin{array}{l}3.3^{\mathrm{cA}} \\
(2.7)\end{array}$ & $\begin{array}{l}3.2^{\mathrm{aB}} \\
(5.6)\end{array}$ & $\begin{array}{c}3.3^{\mathrm{cA}} \\
(0)\end{array}$ & $\begin{array}{l}3.1^{\mathrm{bB}} \\
(4.7)\end{array}$ & $\begin{array}{l}3.3^{\mathrm{abA}} \\
(23.0)\end{array}$ & $\begin{array}{l}3.2^{\mathrm{aB}} \\
(3.3)\end{array}$ \\
\hline $\begin{array}{c}\text { Lactose } \\
(\%)\end{array}$ & $\begin{array}{c}4.4^{\mathrm{abA}} \\
(\mathrm{N})\end{array}$ & $\begin{array}{c}4.4^{\mathrm{aA}} \\
(\mathrm{N})\end{array}$ & $\begin{array}{c}4.4^{\mathrm{aA}} \\
(\mathrm{N})\end{array}$ & $\begin{array}{c}4.5^{\mathrm{bB}} \\
(\mathrm{N})\end{array}$ & $\begin{array}{c}4.4^{\mathrm{daA}} \\
(\mathrm{N})\end{array}$ & $\begin{array}{c}4.4^{\mathrm{aA}} \\
(\mathrm{N})\end{array}$ & $\begin{array}{c}4.4^{\mathrm{bdeA}} \\
(\mathrm{N})\end{array}$ & $\begin{array}{c}4.4^{\mathrm{aB}} \\
(\mathrm{N})\end{array}$ & $\begin{array}{c}4.4^{\mathrm{aeA}} \\
(\mathrm{N})\end{array}$ & $\begin{array}{c}4.5^{\mathrm{bB}} \\
(\mathrm{N})\end{array}$ & $\begin{array}{c}4.3^{\mathrm{cA}} \\
(\mathrm{N})\end{array}$ & $\begin{array}{c}4.4^{\mathrm{cB}} \\
(\mathrm{N})\end{array}$ \\
\hline $\begin{array}{l}\mathrm{TS} \\
(\%)\end{array}$ & $\begin{array}{c}12.7^{\mathrm{aA}} \\
(\mathrm{N})\end{array}$ & $\begin{array}{c}12.5^{\mathrm{adB}} \\
(\mathrm{N})\end{array}$ & $\begin{array}{c}12.5^{\mathrm{bdA}} \\
(\mathrm{N})\end{array}$ & $\begin{array}{c}12.3^{\mathrm{beB}} \\
(\mathrm{N})\end{array}$ & $\begin{array}{c}12.4^{\mathrm{bA}} \\
(\mathrm{N})\end{array}$ & $\begin{array}{c}12.2^{\mathrm{bB}} \\
(\mathrm{N})\end{array}$ & $\begin{array}{c}12.8^{\mathrm{cA}} \\
(\mathrm{N})\end{array}$ & $\begin{array}{c}12.5^{\mathrm{aB}} \\
(\mathrm{N})\end{array}$ & $\begin{array}{c}12.7^{\mathrm{acA}} \\
(\mathrm{N})\end{array}$ & $\begin{array}{c}12.0^{\mathrm{cB}} \\
(\mathrm{N})\end{array}$ & $\begin{array}{c}12.6^{\mathrm{adA}} \\
(\mathrm{N})\end{array}$ & $\begin{array}{c}12.4^{\mathrm{deB}} \\
(\mathrm{N})\end{array}$ \\
\hline $\begin{array}{c}\text { NFS } \\
(\%)\end{array}$ & $\begin{array}{l}8.7^{\mathrm{acA}} \\
(14.4)\end{array}$ & $\begin{array}{l}8.6^{\mathrm{adB}} \\
(19.0)\end{array}$ & $\begin{array}{c}8.7^{\mathrm{aA}} \\
(56.5)\end{array}$ & $\begin{array}{c}8.7^{\text {beA }} \\
(6.3)\end{array}$ & $\begin{array}{l}8.6^{\mathrm{cA}} \\
(25.2)\end{array}$ & $\begin{array}{l}8.6^{\mathrm{bA}} \\
(7.4)\end{array}$ & $\begin{array}{l}8.7^{\mathrm{adA}} \\
(11.1)\end{array}$ & $\begin{array}{c}8.6^{\mathrm{aB}} \\
(19.7)\end{array}$ & $\begin{array}{l}8.7^{\text {bdA }} \\
(11.9)\end{array}$ & $\begin{array}{c}8.6^{\mathrm{cB}} \\
(18.2)\end{array}$ & $\begin{array}{l}8.6^{\mathrm{cA}} \\
(24.0)\end{array}$ & $\begin{array}{l}8.6^{\mathrm{deA}} \\
(20.6)\end{array}$ \\
\hline
\end{tabular}

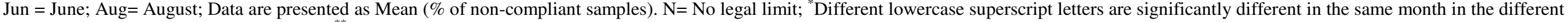
municipalities by Kruskal-Wallis ( $<<0.05)$. ${ }^{* *}$ Different uppercase superscript letters are significantly different in the same municipality in the months of June and August by Mann-Whitney ( $\left.<0.05\right)$. 


\section{DISCUSSION}

Several factors can alter milk composition, such as physiological factors related to breed, age, days in milk, and those related to seasonality, nutrition, herd health and mastitis, which also affect SCC (FONSECA; SANTOS, 2000; BASTAN et al., 2008; TEIXEIRA et al., 2003).

High SCC is related to decreased milk yield from the cow, increased discarding of milk from antibiotic-treated cows and other costs related to early drying off or culling of cows (MACHADO et al., 2000). A small number of mastitis cases was observed amongst the most specialized dairy farms, contributing to lower SCC and better quality milk was produced (MARTINS, 2007). Research found $49 \%$ small dairy producers did not comply with milk regulation whilst larger dairy producers were in compliance (RIBEIRO JUNIOR et al., 2015). Increase in SCC results in alterations in lactose, protein and fat contents in milk. These may be mainly attributed to damages in the blood-milk barrier, with efflux of lactose and influx of blood proteins to the milk, and the synthesis capacity the glandular epithelium is reduced in consequence of the damage (AUDIST et al., 1995). High TBC indicates poor milking hygiene practices and/or milk cooling failure (VALLIN et al., 2009).

Non-fat solids account for milk solids after water and fat removal, and can vary according to herd nutritional management differences that are markedly evident among the municipalities considered in the present investigation. Milk fat is highly influenced by fiber levels in the cow diet and inversely proportional to milk production (NORO et al., 2006; SOUZA et al., 2010). Serum proteins (immunoglobulins and albumins), casein, lactoalbumin and lactoglobulin account for the crude protein in milk. Casein levels can be diminished by proteolytic activity of blood plasmin or by decreased synthesis caused by cellular damage during mastitis. Damage to the blood-milk barrier increase the influx of serum proteins to the mammary gland (AUDIST et al., 1995). There are no minimum parameters regarding lactose and total solids in refrigerated raw milk (Brasil, 2011). Data were analyzed from the production of a dairy herd with 410 dairy cows over five years and the authors reported lactose and total solids mean values of 4.51 $\%$ and $12.48 \%$, respectively (REIS et al., 2012).

Lactose is synthetized by epithelial cells from mammal parenchyma and inflammation may result in a decrease of its synthesis by the gland (SHUSTER et al., 1991). As lactose regulates osmotic pressure of the mammary gland, so that a larger lactose production results in a larger milk yield (PERES, 2001).

Research concluded that higher total solids levels are influenced by higher lipids contents (ZANELA et al., 2006). Other factors such as SCC, season (BOTARO et al., 2011) and breed (NÓBREGA AND LANGONI, 2011) can also influence milk total solids.

\section{CONCLUSIONS}

Overall refrigerated raw milk delivered to a dairy industry in North Parana did not comply with the minimal raw milk quality requirements with respect to total bacterial and somatic cell counts, nor was it in accordance with the stricter Brazilian federal milk ordinace immediately after its implementation on July $1^{\text {st }}, 2014$. On the other hand, compositional regulated requirements of milk (fat, protein and non-fat solids) did not seem to be a big challenge for the studied dairy cooperative to comply with the revised changes proposed by the Brazilian milk regulation.

RESUMO: Limites de contagem de células somáticas (CCS) e contagem bacteriana total (CBT) em leite cru refrigerado estão mais estritos no Brasil desde Julho de 2014. Foram avaliadas 11051 amostras de leite entregues para beneficiamento no Estado do Paraná, Brasil, por produtores de leite e cooperados e verificou-se se estas atendiam aos requisitos governamentais e às mudanças estabelecidas. A qualidade do leite foi avaliada de Junho a Agosto de 2014 em fazendas leiteiras de três estados. Os dados foram obtidos por espectroscopia em infravermelho e citometria de fluxo. CCS foi superior em Junho $(\mathrm{p}<0,05)$, quando foi observado maior número de amostras e valores médios que não estavam de acordo com os padrões legais. A cidade do Estado de Mato Grosso do Sul foi a única que cumpriu com os limites legais requeridos ao longo do período. CBT não apresentou variação $(\mathrm{p}>0,05)$ ao longo do trimestre, e nenhuma das cidades apresentou valores dentro do limite estabelecido para CBT. Proteína, gordura e sólidos não gordurosos estavam de acordo com os limites requeridos. Sólidos totais e lactose variaram ao longo dos meses $(\mathrm{p}<0,05)$, com valores elevados para sólidos totais em Junho e para lactose em Agosto. Amostras de leite não estavam de acordo com os requisitos mínimos de CCS e CBT, e não estão ajustadas aos padrões de qualidade mais rígidos.

PALAVRAS-CHAVE: CBT. CCS. Composição. Regulamentação. Qualidade. 


\section{REFERENCES}

ARCURI, E. F.; BRITO, M. A. V. P.; BRITO, J. R. F. et al. Microbiological quality of refrigerated milk on farms. Braz J Vet Res An Sci, São Paulo, v. 58, p. 440-446, 2006.

AUDIST, M. J.; COATS, S.; ROGERS, G. L.; MCDOWELL, G. H. Changes in the compositional of milk from healthy and mastitic dairy cows during the lactation cycle. Aust J Exp Agr, Collingwood, v. 35, p. 427-436, 1995. https://doi.org/10.1071/EA9950427

BASTAN, A.; KAÇAR, C.; ACAR, D. B. et al. Investigation of the incidence and diagnosis of subclinical mastitis in early lactation period cows. Turk J Vet Anim Sci, Kırıkkale, v. 32, p. 119-121, 2008.

BOTARO, B. G.; CORTINHAS, C. S.; MESTIERI, L. et al. Milk composition and protein fraction from commercial dairy farms. Vet e Zootec, Botucatu, v. 18, p. 81-91, 2011.

BRASIL (2011) Ministério da Agricultura, Pecuária e Abastecimento. Instrução Normativa 62, de 29 de Dezembro de 2011. Aprova o Regulamento Técnico de Produção, Identidade e Qualidade do Leite tipo A, o Regulamento Técnico de identidade e Qualidade de Leite Cru Refrigerado, o Regulamento Técnico de Identidade e Qualidade de Leite pasteurizado e o Regulamento Técnico da Coleta de Leite Cru Refrigerado e seu Transporte a Granel. Diário Oficial [da] República Federativa do Brasil, Seção 1, 30 de Dezembro de 2011.

FONSECA, L. F. L.; SANTOS, M. V. Qualidade do leite e controle de mastite. Editorial Lemos, São Paulo, 2000.

INSTITUTO BRASILEIRO DE GEOGRAFIA E ESTATÍSTICA, IBGE (2014) Estatística da Produção Pecuária. http://www.ibge.gov.br/home/estatistica/indicadores/agropecuaria/producaoagropecuaria/abate-leitecouro-ovos_201401_publ_completa.pdf. Accessed 16 June 2015

MACHADO, P. F.; PEREIRA, A. R.; SARRIES, G. A. Bulk Tank Milk Composition from Brazilian Herds Distributed by its Somatic Cell Count. R Bras Zootec, Viçosa, v. 29, p. 2765-3768, 2000.

MARTINS, P. R. G.; FISCHER, V.; RIBEIRO, M. E. R. et al. Milk yield and quality at production systems of the dairy region of Pelotas, RS, Brazil. Ciênc Rural, Santa Maria, v. 37, p. 212-217, 2007.

https://doi.org/10.1590/S0103-84782007000100034

NÓBREGA, D. B.; LANGONI, H. Breed and season influence on milk quality parameters and in mastitis occurrence. Pesq Vet Brasil, Seropédica, v. 31, p. 56-65, 2011.

NORO, G.; GONZÁLEZ, F. H. D.; CAMPOS, R.; DÜRR, J. W. Effects of environmental factors on milk yield and composition of dairy herds assisted by Cooperatives in Rio Grande do Sul, Brazil. R Bras Zootec, Viçosa, v. 35, p. 1129-1135, 2006. https://doi.org/10.1590/S1516-35982006000400026

PERES, J. R. O leite como ferramenta do monitoramento nutricional. In: Felix HD (ed) Uso do leite para monitorar a nutrição e o metabolismo de vacas leiteiras, UFRGS, Porto Alegre, pp 30-45, 2001.

REIS, A. M.; COSTA, M. R.; COSTA, R. G. et al. Effect of the racial group and number of lactation on the productivity and composition of bovine milk. Semin- Cienc Agrar, Londrina, v. 33, p. 3421-3436, 2012. https://doi.org/10.5433/1679-0359.2012v33Supl2p3421

RIBEIRO JUNIOR, J. C., TAMANINI, R., SILVA, L. C. C., BELOTI, V. Quality of milk produced by small and large dairy producers. Semin- Cienc Agrar, Londrina, v. 36, p. 883-888, 2012.

https://doi.org/10.5433/1679-0359.2015v36n2p883 
SHUSTER, D. E.; HARMON, R. J.; JACKSON, J. A.; HEMKEN, R.W. Suppression of milk production during endotoxin-induced mastitis. J Dairy Sci, Madison, v. 74, p. 3763-3774, 1991.

https://doi.org/10.3168/jds.S0022-0302(91)78568-8

SOUZA, R.; SANTOS, G. T.; VALLOTO, A. A. et al. Milk production and quality of Holstein cows in function of the season and calving order. Rev Bras Saúde Prod Anim, Salvador, v. 11, p. 484-495, 2010.

TEIXEIRA, N. M.; FREITAS, A. F.; BARRA, R. B. Environmental factors influencing monthly variation of milk composition and somatic cell counts in herds of the State of Minas Gerais. Arq Bras Med Vet Zootec, Belo Horizonte, v. 55, p. 491-499, 2003. https://doi.org/10.1590/S0102-09352003000400016

VALLIN, V. M.; BELOTI, V., BATTAGLINI, A. P. P. et al. Milk quality improvement after implantation of good manufacturing practices. Semin- Cienc Agrar, Londrina, v. 29, p. 181-188, 2009.

https://doi.org/10.5433/1679-0359.2009v30n1p181

ZANELA, M. B.; FISCHER, V.; RIBEIRO, M. E. R. et al. Milk quality in production systems in the Southern region of Rio Grande do Sul. Pesq Agrop Bras, Brasília, v. 41, p. 153-159, 2006.

https://doi.org/10.1590/S0100-204X2006000100021 